\title{
Proceeding
}

Supplementary Issue: Winter Conferences of Sports Science. Costa Blanca Sports Science Events, 24 April 2020. Alicante, Spain.

\section{The effect of pilates exercises on some physical components among first stage female students of the Faculty of Physical Education and Sports Sciences Wasit University}

\author{
GHFRAN MUHAMMAD TOHMEA , NAJAM RABH NAJAM, WISSAM MUHAMMAD TOHMEA \\ Faculty of Physical Education and Sport Sciences, University of Wasit, Iraq
}

\begin{abstract}
Fitness exercises with all their components have been widespread in recent years and have become largely practiced in most fitness centres as they aim to develop functional devices abilities and capabilities, which helps to speed performance, movement lightness and body agility. Most of first stage practical materials in order to be practiced demands strength, lightness and agility and since the researchers are working in the educational profession noticed a clear weakness in students' performance for movements and their inability to perform them properly due to the noticeable increase in weight and the lack of interest in applying modern methods in education or practical application which contributed significantly to the lack of movement and performance ineffectiveness among the students. The researchers used the experimental method with one experimental group with tribal and dimensional tests because it fits the research problem nature, the research community was identified by first stage students from the Faculty of Physical Education and Sports Sciences, Wasit University deliberately, where the number of community members were 48 students, the sample was selected randomly the researchers conducted the exploratory experiment on the group, and conducted a training unit for the Pilates exercise which the researchers prepared in the curriculum for the group on the day of $1 / 4 / 2018$. The researchers concluded that Pilates-exercises led to the development of body measurements among the research sample also led to a decrease in weight and thus reduced the body circumference measurements. The researchers recommended using divers training equipment and conducting training courses for trainers.
\end{abstract}

Keywords: Pilates; Agility; Physical exercises; Weight loss.

Cite this article as:

Tohmea, G.M., Najam, N.R., \& Tohmea, W.M. (2020). The effect of Pilates exercises on some physical components among first stage female students of the Faculty of Physical Education and Sports Sciences Wasit University. Journal of Human Sport and Exercise, 15(2proc), S146-S153. doi:https://doi.org/10.14198/jhse.2020.15.Proc2.04

Corresponding author. Faculty of Physical Education and Sport Sciences, University of Wasit, Alkut 52001, Iraq.

E-mail: dr.ghafarsaeedissa@gmail.com

Supplementary Issue: Winter Conferences of Sports Science. Costa Blanca Sports Science Events, 24 April 2020. Alicante, Spain.

JOURNAL OF HUMAN SPORT \& EXERCISE ISSN 1988-5202

(C) Faculty of Education. University of Alicante

doi:10.14198/jhse.2020.15.Proc2.04 


\section{INTRODUCTION}

Fitness exercises with all their components have been widespread in recent years and have become practiced extensively in all fitness centres or other sports stadiums as they aim to develop the abilities and capabilities of functional devices, which helps to speed performance, lightness of movement and agility. The practice of sports aims to develop various elements of fitness in addition to maintaining the health aspects, so the Faculty of Physical Education and Sports Sciences attracts students (male and female) according to certain measurements and specifications commensurate with the nature and requirements of performance during the study period, Therefore, the first stage represents the basis for the rest of the practical stages while it is one of the means of success for the later stages as the students of this stage perform many practical lessons that contribute to raising the level of fitness components (muscle strength, speed, flexibility, agility) Thus maintaining certain limits of weight is suitable for the nature of practical performance, which is not a factor that hinders performance and does not fit with the specifications of the Faculty of Physical Education because the increase in weight attribute to performance speed reduction and loss of aesthetic, which means the loss of fitness required to change the direction of the body or one Parts on the ground or in the air according to skills technical performance requirements, but the failure to adopt the basic exercises effectively will not have a positive impact in achieving the goal in their practice and this will have negative consequences on the female students abilities in performing different sports activities lightly And agility and aesthetic slackness due to sagging body as a result of weight gain and therefore not using effective methods in the practical lessons application. Hence the importance of research, which lies in the use of modern training methods that provide suspense and excitement, which drives students to exercise with enthusiasm, motivation and acceptance despite the difficulty of performing them in some cases. One of these methods is the style of Pilates, which is a comprehensive motor exercise that works on the development and rehabilitation of the body parts and depends on the strength of performance as well as the balance in the parts of the body.

\section{Research problem}

In order to apply most of first stage practical materials it needs strength, lightness and agility and since the researcher is working in the educational centre in the college noticed a clear weakness in the performance of students for movements and the inability to implement them properly due to the noticeable increase in weight as well as the lack of interest in applying modern methods in education or practical application, which contributed significantly to the lack of movement and ineffectiveness of performance among female students and therefore the obvious weakness in the performance level, hence the problem of research, which consisted of the use of traditional teaching methods in the courses of physical education and sports sciences so the researcher sought in a serious attempt to introduce Pilates exercises in physical education classes to try to find organized and effective training methods which increase the female students motivation and the desire to work seriously. and thus, reduce the weight gain rate and this will reflect on the sports movements performance speed and the building of balanced bodies with The nature of the performance.

\section{Research aim}

- Preparing Pilates exercises for first stage female students of the Faculty of Physical Education and Sports Sciences Wasit University.

- Knowing the effect of Pilates exercises on some physical components among first stage female students of the Faculty of Physical Education and Sports Sciences Wasit University. 


\section{The research impose}

There are statistically significant differences between tribal and dimensional tests in some physical components among first stage female students of the Faculty of Physical Education and Sports Sciences Wasit University.

\section{Research fields}

Spatial Field: Faculty hall of physical education and sports sciences.

Time domain: 20-2-2019 to 20-6-2019.

Human field: First-stage students.

\section{MATERIAL AND METHODS}

\section{Procedures}

The researcher used the experimental method with a single experimental group with tribal and dimensional testing because it fits the nature of the research problem.

\section{Participants}

The research community was identified by (female first stage students) Faculty of Physical Education and Sports Sciences / Wasit University deliberately, where the number of members of the community (48) female students, while the sample was selected by random lottery method it consisted of (15) students and formed a percentage of (31.25) of the research community and the researcher conducted homogenization on the sample of research variables height, weight and age.

Table 1. Shows the homogeneity of the research sample.

\begin{tabular}{lccccc}
\hline \multicolumn{6}{c}{ Statistical features } \\
\hline Variables & Measurement Unit & Arithmetic Mean & $\begin{array}{c}\text { Standard } \\
\text { Deviation }\end{array}$ & Median & Skewness \\
\hline Body Mass & $\mathrm{Kg}$ & 158.1333 & 6.24347 & 160.000 & 0.478 \\
Age & Year & 21.0667 & 1.33452 & 21.0000 & 0.278 \\
Height & $\mathrm{Cm}$ & 65.6667 & 3.37357 & 65.0000 & 0.672 \\
\hline
\end{tabular}

Gathering information ways:

- Arabic and foreign references.

- The internet.

- Exploratory experiment.

- Tests and measurements.

- Statistical means of (SPSS) System.

\section{Measures}

- 10 Swiss balls.

- 10 Sport cones.

- 10 dumbbells which weighs $2 / 3 / 5 \mathrm{Kg}$.

- 1 whistle.

- Registration form. 
- Body Tape Measure from MyoTape.

- Compact disc (CD).

Research devices:

- 4 electronic watches by anytime co.

- Scale by sartorius co.

- TV by Philips co.

- Voice recorder.

\section{Analysis}

The researcher used the ready-made statistical bag (SPSS) to extract the following laws:

- Percentage law.

- Arithmetic mean.

- Standard deviation.

- Medium.

- Skewness coefficient.

- T-test for interconnected samples.

\section{RESULTS}

Table 2. Shows arithmetic mean, standard deviations and calculated $t$ value and the result of differences between tribal and dimensional testing in some body measurements.

\begin{tabular}{|c|c|c|c|c|c|c|c|c|}
\hline \multirow{3}{*}{$\begin{array}{l}\text { Body } \\
\text { measurements }\end{array}$} & \multicolumn{8}{|c|}{ Statistical features } \\
\hline & \multirow{2}{*}{$\begin{array}{l}\text { Measurement } \\
\text { unit }\end{array}$} & \multicolumn{2}{|c|}{ Tribal test } & \multicolumn{2}{|c|}{$\begin{array}{c}\text { Dimensional } \\
\text { test }\end{array}$} & \multirow{2}{*}{$\begin{array}{c}\text { Calculated } \\
\text { (t) value }\end{array}$} & \multirow{2}{*}{$\begin{array}{l}\text { Honesty } \\
\text { level }\end{array}$} & \multirow{2}{*}{$\begin{array}{c}\text { Significance } \\
\text { level }\end{array}$} \\
\hline & & $S$ & $P$ & $S$ & $P$ & & & \\
\hline Body mass & $\mathrm{Kg}$ & 71.8 & 7.19 & 61 & 5.15 & 2.21 & 0.040 & Significant \\
\hline $\begin{array}{l}\text { Left Upper arm } \\
\text { circumference }\end{array}$ & $\mathrm{cm}$ & 39 & 1.75 & 37 & 1.63 & 6.34 & 0.000 & Significant \\
\hline $\begin{array}{l}\text { Right Upper } \\
\text { arm } \\
\text { circumference }\end{array}$ & $\mathrm{cm}$ & 42.60 & 1.84 & 40.06 & 1.69 & 4.38 & 0.001 & Significant \\
\hline $\begin{array}{l}\text { Waist } \\
\text { circumference }\end{array}$ & $\mathrm{cm}$ & 102.19 & 2.74 & 96.21 & 3.14 & 5.90 & 0.000 & Significant \\
\hline $\begin{array}{l}\text { Abdominal } \\
\text { circumference }\end{array}$ & $\mathrm{cm}$ & 86.2 & 2.29 & 90.85 & 2.90 & 3.34 & 0.005 & Significant \\
\hline $\begin{array}{l}\text { Hip } \\
\text { circumference }\end{array}$ & $\mathrm{cm}$ & 105.46 & 3.87 & 102.33 & 3.17 & 4.37 & 0.001 & Significant \\
\hline $\begin{array}{l}\text { Right thigh } \\
\text { circumference }\end{array}$ & $\mathrm{cm}$ & 43.5 & 4.1 & 48 & 4.03 & 2.21 & 0.04 & Significant \\
\hline $\begin{array}{l}\text { Left thigh } \\
\text { circumference }\end{array}$ & $\mathrm{cm}$ & 44.12 & 4.18 & 48.75 & 4.26 & 2.18 & 0.04 & Significant \\
\hline
\end{tabular}

This chapter includes the presentation of the results of the tests and tribal and dimensional measurements of the research sample and their analysis through the presentation of mathematical mean and standard 
deviations and the value (T) calculated and tabular, and then discussed according to scientific references for the purpose of achieving the objectives of the research and verifying its hypotheses.

\section{Field research procedures}

Identifying the physical measurements used in the research:

After reviewing the scientific sources and references specialized in the physiology of training, some of the physical measurements and tests were selected as follows ${ }^{1}$ :

Virtual weight:

- The unit of measurement used: kilogram and its parts.

- Device used: electronic scale.

- Instructions: The subject stands above the base of the device in the middle of it completely so that the body weight is distributed on both feet and the body is generally erect and the butts are contiguous.

- Registration: Registration is made for the nearest gram.

Upper arm circumference measurements (left and right):

- The unit of measurement used: centimetres and its parts.

- Tool: Leather measuring tape.

- Instructions: The arm is lifted to wrap the tape around the upper arm and return the arm to its normal state so that the tape is read by the researcher without the intense pressure on the subject upper arm.

- Registration: For the nearest 0.1 centimetres.

Waist circumference measurements:

- The unit of measurement used: centimetres and its parts.

- Tool: Leather measuring tape.

- Instructions: The subject stands on both feet moderately, the abdomen is loose, the researcher places the measuring tape at the smallest circumference of the torso and then reads the tape at the end of the Inhalation process without the intense pressure on the tape on the waist of the subject

- Registration: For the nearest 0.1 centimetres.

Abdominal circumference measurements:

- The unit of measurement used: Meter and its parts.

- Tool: Leather measuring tape.

- Instructions: The subject stands on both feet moderately the researcher wraps the measuring tape around the subject abdomen without tightening the tape hardly while reading the measurements the reading should be taken right after the end of the exhale process.

- Registration: For the nearest 0.1 centimetres.

Hip circumference measurements:

- The unit of measurement used: Meter and its parts.

1 Suleiman, A.(1995). Encyclopedia of Modern Gymnastics, 1st edition: Amman, Dar Al Fikr for Printing, Publishing and Distribution, pp. 537-539. 
- Tool: Leather measuring tape.

- Instructions: The subject stands on both feet moderately the researcher wraps the measuring tape around the subject hip the researchers should squat in order to read the measurements without applying had pressure on the subject hip.

- Registration: For the nearest 0.1 centimetres.

Upper thigh circumference measurements (left and right):

- The unit of measurement used: centimetres and its parts.

- Tool: Leather measuring tape.

- Instructions: The subject should raise her leg and the tape should be wrapped on her upper thigh without returning the thigh to its normal position in which the tape should be researcher without pressing hard on the Thigh.

- Registration: For the nearest 0.1 centimetres.

\section{Exploratory experiment}

The researcher conducted the exploratory experiment on the group, and conducted a training unit for the exercises of (Pilates) which the researcher used in the curriculum prepared for the group and this experiment aimed to:

- Find out how appropriate the nature of the exercises are at the level of the research sample.

- Knowing the constraints and difficulties that may arise in the main experiment.

The results of this experiment included:

All exercises were found to be appropriate to the level of the research sample, and all the obstacles and difficulties were identified to avoid them in the main experiment.

Tribal test:

Tribal tests were conducted on the Sunday (3/3) to $(4 / 3)$, with the conditions related to the tests in terms of space, time and tools used were documented in order to achieve similar conditions and ensure their availability in the dimensional tests.

Training curriculum:

Pilates Exercises

The researcher has been preparing training sought to develop some elements of fitness and body measurements (Pilates-method) on the experimental group using the continuous training method.

Main experience:

The main experiment was started on Wednesday (6/3) and completed on Sunday (7/4), which is as follows: The number of training units prepared by the researcher (11) training units distributed over 4 weeks, 3 training units per week.

The researcher used the method of continuous training. 
The severity of the training load started from $60 \%$ and reached $85 \%$.

Dimensional test:

The dimensional tests were carried out on the day () and up to the day () under the same conditions as tribal tests in terms of time, place, tools and devices used.

\section{DISCUSSION}

Table 2 shows that there are significant differences between tribal tests and dimensional tests in body measurements (body mass, left upper arm circumference, right upper arm circumference waist circumference, abdominal circumference, hip circumference, right thigh circumference, left thigh circumference) in favour of the dimensional test, The reason is the distinction of moving away from routine training and using various exercises and using the musical rhythm for more excitement, enthusiasm and exerting the greatest effort without getting bored, so the great physical effort increases the efficiency of the working muscle groups. This leads to a slight increase in muscle weight in the body and a significant decrease in the percentage of grease and this is an indicator of increased level of muscle strength and oxygen efficiency and then decreased weight, and this is consistent with what Ibrahim Ahmed Salama, 2000 indicated that the return from regular physical exercises leads to a reduction of For the fat tissue in the muscles, therefore the lack of peripheral measurements and weight is due to the lack of fatty tissue and is often more than the increase in the size of the muscle mass ${ }^{2}$. As Pilates-exercises start from the centre of the body when starting the movement which is the basis of strength and after which the burning of fat is large in this area, and also decrease body measurements, as Karon Karter adds that all movements start from the centre as the muscles of the centre support the spine and Internal organs and performance improves, Pilates exercises help build a strong body centre while reducing waist and abdomen circumference ${ }^{3}$.

Sources indicate that the accumulation of fat in the abdominal area is more dangerous health wise than its accumulation in any other area of the body, as it is called central obesity or obesity in the middle of the body, and Simopoulos states that in addition to the degree of obesity, the distribution of fat in the body is another important factor for the risks of exposure to diseases related to obesity, obesity is based on two types of fat distribution: upper body obesity (abdominal obesity or central obesity or so-called apple type), and the other type is sub-body obesity or pear type ${ }^{4}$. For this reason, the researcher believes that Pilates are very suitable for eliminating central obesity and avoiding its seriousness, since the result of these continuous and organized exercises led to an increase in the rate of fat burning due to increased metabolic rate (BMR) which attributes to a decrease in weight, Osama Kamel and Ibrahim Abd Rabbu mentions after the completion of physical activity, the metabolic rate increases for several hours as the use of calories continues more quickly ${ }^{5}$. In this regard, Noamat Ahmed points out that the continuous work of the muscles requires a steady flow of glycogen to produce movement and when the glycogen (which was present before the start of the exercise) is depleted, the reserve fat provides the body with additional glucose until the exercise stops and so it burns Fat, which leads loss of weight and hence a decrease in body mass indicator and reduced body measurements ${ }^{6}$. Charles states that there is evidence on regular physical activity that it increases metabolic

2 Salama, I.(2000). The Applied Entrance to Measurement in Fitness: Alexandria, Monshaat El-Maaref, p. 122.

${ }^{3}$ Karter,K. op.cit,P 47.

${ }^{4}$ Simopoulos,A.P. (2005). Nutrition and Fitness, Garger AG, Switzerland, P 9.

${ }^{5}$ Kamel,O. \&Abd Rabou,i.(1998). The sport of walking is an introduction to achieving mental and physical health: Cairo, Dar AlFikr Al-Arabi, p. 295.

${ }^{6}$ Abdel-Rahman,N.(2000). Aerobic activities: Maarif facility, Alexandria, p. 25. 
rate and this avoid weight gain ${ }^{7}$. All changes in physical composition are due to physiological changes in the body as a result of aerobic physical activity (Pilates - Cardio). Abu Ala Abdel Fattah and Ahmed Nasreddine states that "the decrease in fat content as a result of various sports programs geared to weight loss is based solely on physiological processes associated with energy production and aerobic metabolism ${ }^{8}$.

\section{CONCLUSION}

1- Pilates-exercises led to the development of physical measurements among the research sample.

2- Pilates-exercises have reduced weight and thus reduced the researched body circumference measurements.

3- The use of Pilates-training sought to increase the desire, and excitement among female students to practice the training units with enthusiasm and without boredom.

\section{Recommendations}

1- Diversify equipment and training tools when applying Pilates-training and not just relay on free exercises.

2- Conducting training courses by the concerned authorities for trainers to make them aware of the Pilates programs.

3- Conducting studies using Pilates equipment and tools to determine their effect on the development of strength and lengthening of the muscles of the body.

4- Encourage the use of Pilates-Cardio exercises in fitness centres for their important role in the development of the overall health of individuals.

\section{REFERENCES}

Abdel-Rahman, N. (2000). Aerobic activities: Maarif facility, Alexandria, p. 25.

Ahmed, A. \& Sayed, A. (2008). Physiology of Fitness, 2nd floor: Cairo, Dar Al-Fikr Al-Arabi, pp. 72-73.

Charles B. Corbin et al. (2009). Concepts of Physical Fitness, 15th ed,USA:McGraw Hill Companies, Inc, $P 248$.

Kamel, O. \& Abd Rabou, I. (1998). The sport of walking is an introduction to achieving mental and physical health: Cairo, Dar Al-Fikr Al-Arabi, p. 295.

Karter, K. op.cit, P 47.

Salama, I. (2000). The Applied Entrance to Measurement in Fitness: Alexandria, Monshaat El-Maaref, p. 122.

Simopoulos, A .P. (2005). Nutrition and Fitness, Garger AG, Switzerland, P 9.

Suleiman, A. (1995). Encyclopedia of Modern Gymnastics, 1st edition: Amman, Dar Al Fikr for Printing, Publishing and Distribution, pp. 537-539.

\section{(9) $\odot \Theta \Theta$}

This work is licensed under a Attribution-NonCommercial-NoDerivatives 4.0 International (CC BY-NC-ND 4.0).

${ }^{7}$ Charles B. Corbin et al(2009). Concepts of Physical Fitness, 15th ed,USA:McGraw Hill Companies, Inc, P 248.

${ }^{8}$ Ahmed,A.\& Sayed,A.(2008). Physiology of Fitness, 2nd floor: Cairo, Dar Al-Fikr Al-Arabi, pp. 72-73. 